\title{
Effect of Hot Extrusion on the Microstructure and Mechan- ical Properties of the SiCp/Mg-9Al-1Zn Nanocomposite Fabricated by Different Stir Time
}

\author{
Wang Wanhua $^{1,2}$, Wang Hongxia ${ }^{1,2}$, Ren Guangxiao ${ }^{1,2}$, Cheng Weili ${ }^{1,2}$, Zhang Shaoxiong ${ }^{1,2}$ \\ ${ }^{1}$ Shanxi Key Laboratory of Advanced Magnesium Based Materials, Taiyuan University of Technology, Taiyuan 030024, China; ${ }^{2}$ Key Labor- \\ atory of Interface Science and Engineering in Advanced Materials, Taiyuan 030024, China
}

\begin{abstract}
SiC nanoparticles reinforced Mg-9Al-1Zn magnesium matrix composite was fabricated by stir casting and hot extrusion. Effect of hot extrusion on microstructure and mechanical properties of SiCp/Mg-9Al-1Zn nanocomposite stirring for 10 min and 30 min was researched. The results show that the grains of the matrix in the as-cast $\mathrm{SiCp} / \mathrm{Mg}-9 \mathrm{Al}-1 \mathrm{Zn}$ nanocomposite stirring for $30 \mathrm{~min}$ are mainly refined. But the mechanical properties of nanocomposite decline due to the increase of agglomerated $\mathrm{SiC}$ nanoparticles and $\mathrm{Mg}_{17} \mathrm{Al}_{12}$ phases with network morphology along the grain boundaries. After hot extrusion, a bimodal microstructure composed of alternate arrays of fine DRXed grains and relatively coarse DRXed grains forms. Particularly, for extruded nanocomposites stirring for $30 \mathrm{~min}$, the fine DRXed region increases and the distribution of SiC nanoparticles is more homogenous, which exhibits superior mechanical properties compared with as-extruded SiCp/Mg-9Al-1Zn nanocomposite stirring for $10 \mathrm{~min}$.
\end{abstract}

Key words: $\mathrm{SiCp} / \mathrm{Mg}-9 \mathrm{Al}-1 \mathrm{Zn}$ nanocomposite; stir time; bimodal microstructure; mechanical properties

Magnesium alloys have gained more attention in scientific research and commercial application due to high specific strength and high specific modulus. However, relatively low strength, poor room temperature ductility and high coefficient of thermal expansion restrict their widespread application ${ }^{[1-4]}$. Magnesium matrix composites can provide positive mechanical properties which are superior to magnesium alloys. Particularly, particles reinforced magnesium matrix composite have been widely used because of low cost and simple fabrication technology ${ }^{[5-7]}$. In recent years, the use of nanoparticles as reinforcement phase has inspired considerable research interest since nanoparticles can lead to potential improvements in strength and ductility.

To add nanoscale size particles in matrix preferably, semisolid stirring casting is an simple and effective method compared with other ways such as powder metallurgy, squeeze cast, disintegrated melt deposition, infiltration and self-propagating high-temperature synthesis ${ }^{[8]}$. Semisolid stirring can be used to incorporate nanoparticles and disperse the nanoparticles ${ }^{[9-11]}$. It has been investigated that stir time has significant impact on microstructure and mechanical properties of magnesium matrix composite. When stir time is short, the grain size of the matrix in the composite is not decreased obviously. The as-cast composites show better mechanical properties due to fine $\mathrm{Mg}_{17} \mathrm{Al}_{12}$ phase along the grain boundaries. When stir time is long, the matrix grain is refined obviously while the amount of the refined $\mathrm{Mg}_{17} \mathrm{Al}_{12}$ phase along the grain boundaries decreases ${ }^{[12,13]}$. With the decrease of refined $\mathrm{Mg}_{17} \mathrm{Al}_{12}$ phases and the increase of $\mathrm{SiC}$ nanoparticles agglomeration, it would decrease the mechanical properties of as-cast composite ${ }^{[12]}$. If many uniform $\mathrm{Mg}_{17} \mathrm{Al}_{12}$ particles and homogeneously dispersed $\mathrm{SiC}$ nanoparticles exist in $\mathrm{SiC}$ nanocomposite reinforced $\mathrm{Mg}-\mathrm{Al}$ composite, it would benefit mechanical properties of nanocomposite ${ }^{[14]}$. Exactly, hot ex-

Received date: October 25, 2016

Foundation item: National Natural Science Foundation of China (51301118, 51404166); International Cooperation in Shanxi (2014081002); Technological Innovation Programs of Higher Education Institutions in Shanxi (2013108)

Corresponding author: Wang Hongxia, Ph. D., Professor, College of Materials Science and Engineering, Taiyuan University of Technology, Taiyuan 030024, P. R. China, Tel: 0086-351-6018398, E-mail: wanghxia1217@163.com 
trusion could be applied to break $\mathrm{Mg}_{17} \mathrm{Al}_{12}$ phase into particles and improve $\mathrm{SiC}$ nanoparticles distribution. Based on the result, the mechanical properties of the nanocomposite containing plenty of coarse $\mathrm{Mg}_{17} \mathrm{Al}_{12}$ phases stirring for longer time would be likely to increase more significantly after extrusion while nanocomposite stirring for short time exhibits better as-cast mechanical properties.

To confirm the validity of this idea, $1 \mathrm{wt} \% \mathrm{SiC}$ nanoparticles reinforced Mg-9Al-1Zn magnesium matrix composite stirring for $30 \mathrm{~min}$ was subjected to hot extrusion, and the resulting microstructure and mechanical properties are herein discussed in comparison to those of an as-extruded $\mathrm{SiCp} / \mathrm{Mg}-9 \mathrm{Al}-1 \mathrm{Zn}$ nanocomposite stirring for $10 \mathrm{~min}$.

\section{Experiment}

$\mathrm{Mg}-\mathrm{Al}-\mathrm{Zn}$ alloy with the nominal composition of $\mathrm{Mg}-9 \mathrm{Al}-1 \mathrm{Zn}$ was used as the matrix alloy. SiC nanoparticles with an average diameter of $60 \mathrm{~nm}$ and weight fraction(wt\%) of $1 \%$ were selected as the reinforcement. SiCp/Mg-9Al-1Zn magnesium matrix nanocomposites were fabricated by stir casting. The whole fabrication process was conducted in a protective atmosphere of $\mathrm{CO}_{2}$ and $\mathrm{SF}_{6}$ to avoid burning ${ }^{[15]}$. Mg-9Al-1Zn alloy was molten at $720^{\circ} \mathrm{C}$, and then cooled to $590{ }^{\circ} \mathrm{C}$ which made the matrix alloy in the semi-solid condition. The $\mathrm{SiC}$ particles which were preheated to $550{ }^{\circ} \mathrm{C}$ were quickly added into the molten $\mathrm{Mg}-9 \mathrm{Al}-1 \mathrm{Zn}$ alloy. The mixture was stirred for 10 and $30 \mathrm{~min}$. After adequately stirring the melt, the melt was rapidly reheated to $720{ }^{\circ} \mathrm{C}$ and held at this temperature for $30 \mathrm{~min}$. Then the melt was cooled to $690{ }^{\circ} \mathrm{C}$ and poured into a preheated steel mould $\left(300^{\circ} \mathrm{C}\right)$. The specimens for extrusion were machined to $\Phi 30 \mathrm{~mm} \times 50 \mathrm{~mm}$ from as-cast ingots. Subsequently, the specimens were extruded at $360{ }^{\circ} \mathrm{C}$ with the ratio of $10: 1$.

Microstructure of the as-cast and as-extruded composites was determined by a Leica DM2500M optical microscopy(OM) and a Mira3 Tescan scanning electron microscopy(SEM) equipped with an energy dispersive X-ray spectrometer(EDS). The samples were ground, polished and etched in acetic picral $[5 \mathrm{~g}$ picric acid $+10 \mathrm{~mL}$ acetic acid $+78 \mathrm{~mL}$ ethanol+7 $\mathrm{mL} \mathrm{H}_{2} \mathrm{O}$ ]. The average grain size in the nanocomposite was analyzed from microstructure image using Image-Pro
Plus software. Tensile tests were carried out at room temperature using a DNS 100 machine with a speed of $0.5 \mathrm{~mm} / \mathrm{min}$.

\section{Results and Discussion}

\subsection{Microstructures of as-cast $\mathrm{SiCp} / \mathrm{Mg}-9 \mathrm{Al}-1 \mathrm{Zn}$} nanocomposite fabricated by different stir time

Fig. 1 shows the typical OM and SEM images of as-cast SiCp/Mg-9Al-1Zn nanocomposite with different stir time. As shown in Fig.1a and 1b, the matrix grain of as-cast $\mathrm{SiCp} / \mathrm{Mg}-9 \mathrm{Al}-1 \mathrm{Zn}$ nanocomposite stirring for $30 \mathrm{~min}(\sim 60 \mu \mathrm{m})$ is refined compared with as-cast nanocomposite stirring for 10 $\min (\sim 100 \mu \mathrm{m})$. It can be observed from Fig.1c that the microstructure of as-cast $\mathrm{SiCp} / \mathrm{Mg}-9 \mathrm{Al}-1 \mathrm{Zn}$ nanocomposite stirring for $10 \mathrm{~min}$ is composed of matrix phase (Fig.1c-A) and secondary phase. Besides, the secondary phase with eutectic (Fig.1c-B) and lamellas (Fig.1c-C) morphologies can be found at the interior and boundary of grains. When the stir time is 30 min, the lamellar secondary phase (Fig.1d-D) will increase and form network morphology in the nanocomposite, as shown in Fig.1d. The EDS results of points "A", "B", "C" and "D" are demonstrated in Table 1. By EDS results, the matrix phase and the secondary phase can be recognized as $\alpha-\mathrm{Mg}$ phase and $\mathrm{Mg}_{17} \mathrm{Al}_{12}$ phase, respectively.

As shown in Fig. 2, the composition of the $\mathrm{SiC}$ nanoparticle dense zones was investigated by EDS. Analyzing an area of SEM micrograph, EDS of Si K demonstrates that composition of the nanoparticles is $\mathrm{SiC}$ nanoparticles. For as-cast $\mathrm{SiCp} / \mathrm{Mg}-9 \mathrm{Al}-1 \mathrm{Zn}$ nanocomposite stirring for $10 \mathrm{~min}$, the distribution of $\mathrm{SiC}$ nanoparticle in the nanocomposite is uniform outside a few nanoparticle clusters located at the grain boundaries, as shown in Fig.2a. But for that stirring for $30 \mathrm{~min}$, much $\mathrm{SiC}$ nanoparticle clusters locate at the grain boundaries, as shown in Fig.2b. It has been well documented that many $\mathrm{SiC}$ particles are pushed ahead by liquid-solid interface during solidification process with increasing the stirring time ${ }^{[16]}$.

The microstructure of nanocomposite usually depends on the nucleation stage and subsequent growth condition. The "push" effect of the solidification front on the insoluble solid nanoparticles may cause the nuclei clusters along grain boundaries $^{[12]}$. With increasing the stir time, much more SiC
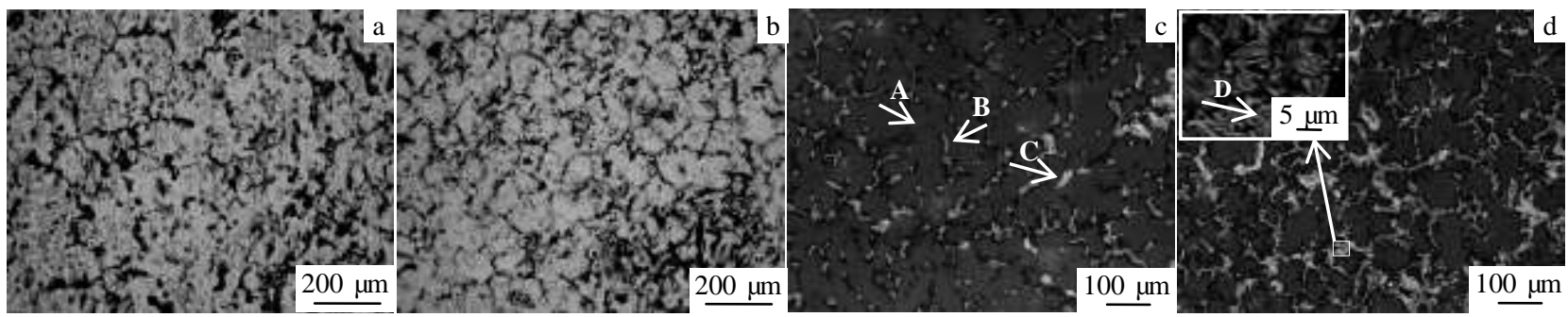

Fig.1 OM (a, b) and SEM (c, d) images of as-cast SiCp/Mg-9Al-1Zn nanocomposite with different stir time: (a, c) stirring for $10 \mathrm{~min}$ and $(\mathrm{b}, \mathrm{d})$ stirring for $30 \mathrm{~min}$ 
Table 1 EDS results of point A, B, C, and D in Fig.1c and 1d (at\%)

\begin{tabular}{ccccc}
\hline \multirow{2}{*}{ Point } & \multicolumn{3}{c}{ Element } & \multirow{2}{*}{ Possible compounds } \\
\cline { 2 - 4 } & $\mathrm{Mg}$ & $\mathrm{Al}$ & $\mathrm{Zn}$ & \\
\hline $\mathrm{A}$ & 86.8 & 11.8 & 1.4 & $\alpha-\mathrm{Mg}$ \\
$\mathrm{B}$ & 61.2 & 37.6 & 1.2 & $\mathrm{Mg}_{17} \mathrm{Al}_{12}$ \\
$\mathrm{C}$ & 66.3 & 31.6 & 2.1 & $\mathrm{Mg}_{17} \mathrm{Al}_{12}$ \\
$\mathrm{D}$ & 64.2 & 34.3 & 1.5 & $\mathrm{Mg}_{17} \mathrm{Al}_{12}$ \\
\hline
\end{tabular}

particles clusters along grain boundaries act as the nuclei, which increase the heterogeneous nucleation. In addition, SiC nanoparticles clusters along grain boundaries can restrict growth of grains during solidification. Thus, the grain refinement occurs in as-cast $\mathrm{SiCp} / \mathrm{Mg}-9 \mathrm{Al}-1 \mathrm{Zn}$ nanocomposite stirring for $30 \mathrm{~min}$. Furthermore, it is well known that a large amount of $\mathrm{Mg}_{17} \mathrm{Al}_{12}$ phases along the grain boundaries change to lamellae after addition of SiC nanoparticles ${ }^{[10]}$. For nanocomposite stirring for 30 min, grain boundaries increase with grain refinement, which can lead to the increase of precipitated lamellar $\mathrm{Mg}_{17} \mathrm{Al}_{12}$ phase along the grain boundary.

2.2 Effect of hot extrusion on microstructures of SiCp/Mg-9Al-1Zn nanocomposite fabricated by different stir time

Fig.3 shows the microstructural characteristics parallel to extrusion direction of as-extruded $\mathrm{SiCp} / \mathrm{Mg}-9 \mathrm{Al}-1 \mathrm{Zn}$ nanocomposite. The optical micrographs in Fig. $3 \mathrm{a}$ and $3 \mathrm{~b}$ demonstrate a bimodal microstructure composed of fine DRXed grains and relatively coarse DRXed grains. For as-extruded $\mathrm{SiCp} / \mathrm{Mg}-9 \mathrm{Al}-1 \mathrm{Zn}$ nanocomposite stirring for 30 min, it shows many relatively fine DRXed regions, as shown in Fig.3b. Consequently, the average grain size of as-extruded nanocomposite stirring for $30 \mathrm{~min}$ is refined from $19.28 \mu \mathrm{m}$ to $13.72 \mu \mathrm{m}$ compared with as-extruded nanocomposite stirring for $10 \mathrm{~min}$. The SEM images in Fig.3c and 3d reveal the concentration of finer precipitated $\mathrm{Mg}_{17} \mathrm{Al}_{12}$ particles $(\sim 2 \mu \mathrm{m})$ and relatively lager cracked $\mathrm{Mg}_{17} \mathrm{Al}_{12}$ phases $(\sim 20 \mu \mathrm{m})$ that occurs in the fine DRXed region, while few such particles are seen in the coarse DRXed region, indicating that these $\mathrm{Mg}_{17} \mathrm{Al}_{12}$ particles play an important role in forming DRXed region. It is well know that during hot deformation an incompatibility between deformations occurs at the interface between the soft grains of the $\mathrm{Mg}$ matrix and hard second phases, and that this induces a strong stress concentration which can increase the formation of fine DRXed grains ${ }^{[17]}$. As mentioned above, there are more $\mathrm{Mg}_{17} \mathrm{Al}_{12}$ phases in as-cast $\mathrm{SiCp} / \mathrm{Mg}-9 \mathrm{Al}-1 \mathrm{Zn}$ nanocomposite stirring for $30 \mathrm{~min}$ as compared with nanocomposite stirring for $10 \mathrm{~min}$, which is the reason for the much more $\mathrm{Mg}_{17} \mathrm{Al}_{12}$ particles in as-extruded nanocomposite stirring for $30 \mathrm{~min}$. A multitude of hard $\mathrm{Mg}_{17} \mathrm{Al}_{12}$ particles accelerate the formation of much more DRXed grains during hot extrusion by inducing a stress concentration around these particles. Similarly, fine $\mathrm{Mg}_{17} \mathrm{Al}_{12}$ particles play an important role in restricting DRXed grain growth by creating a pinning effect $^{[18]}$. Thus, the greater number of fine particles dispersing along grain boundaries of the nanocomposite stirring for 30 min (Fig.3d) are considered to increase the fine DRXed grains through an enhanced grain boundary pinning effect.

Fig.4 shows the surface SEM-EDS for as-extruded $\mathrm{SiCp} / \mathrm{Mg}-9 \mathrm{Al}-1 \mathrm{Zn}$ nanocomposite. The EDS of Si K is homogeneous which demonstrates that the distribution of $\mathrm{SiC}$
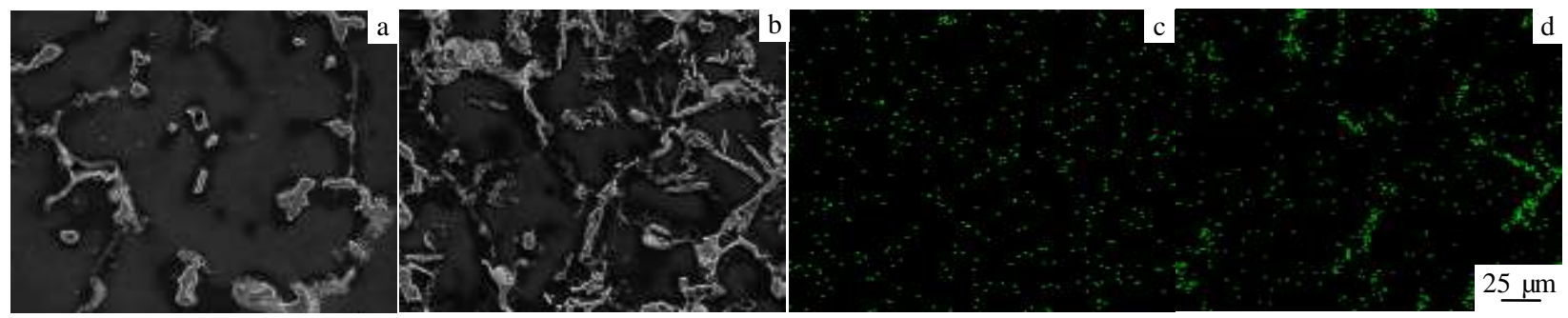

Fig.2 SEM images (a, b) and EDS maps (c, d) of as-cast SiCp/Mg-9Al-1Zn nanocomposite: (a) stirring for $10 \mathrm{~min}$; (b) stirring for $30 \mathrm{~min}$; (c) Si distribution corresponding Fig.2a; (d) Si distribution corresponding Fig.2b
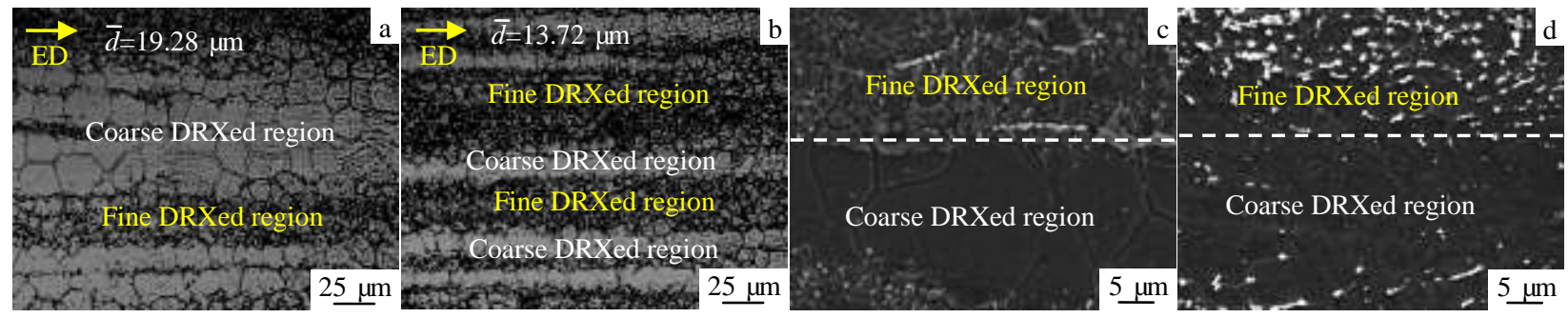

Fig.3 OM (a, b) and SEM (c, d) images of as-extruded SiCp/Mg-9Al-1Zn nanocomposite with different stir time: (a, c) stirring for 10 min; (b, d) stirring for $30 \mathrm{~min}$ 


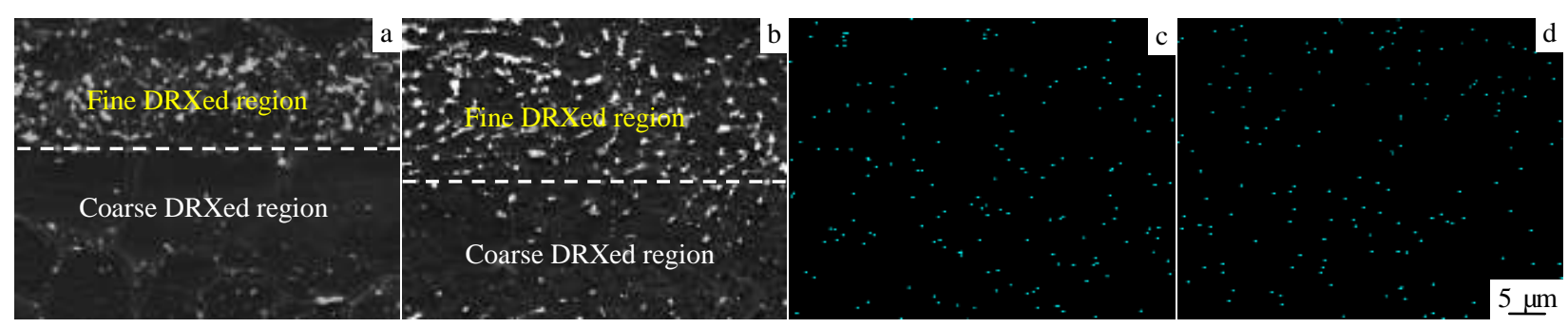

Fig.4 SEM images ( $a, b$ ) and EDS maps (c, d) of as-extruded SiCp/Mg-9Al-1Zn nanocomposite: (a) stirring for 10 min; (b) stirring for 30 min; (c) Si distribution corresponding Fig.4a; (d) Si distribution corresponding Fig.4b

nanoparticle in as-extruded nanocomposite is uniform whether in fine DRXed region or in coarse DRXed region. Thus, fine $\mathrm{Mg}_{17} \mathrm{Al}_{12}$ particles play a major role in the formation of fine DRXed grains.

\subsection{Tensile properties before and after extrusion}

Fig.5 shows the yield strength (YS), ultimate tensile strength (UTS) and elongation of SiCp/Mg-9Al-1Zn nanocomposites in the as-cast and as-extrusion condition. For as-cast $\mathrm{SiCp} / \mathrm{Mg}-9 \mathrm{Al}-1 \mathrm{Zn}$ nanocomposite, the YS, UTS and elongation of the nanocomposite after stirring for $30 \mathrm{~min}$ decline compared with the nanocomposite stirring for $10 \mathrm{~min}$, which can contribute to the increase of the agglomeration of the $\mathrm{SiC}$ nanoparticles and the existence of network $\mathrm{Mg}_{17} \mathrm{Al}_{12}$ phase.

But for as-extruded $\mathrm{SiCp} / \mathrm{Mg}-9 \mathrm{Al}-1 \mathrm{Zn}$ nanocomposite, the nanocomposite stirring for 30 min exhibits superior mechanical properties compared with nanocomposite stirring for 10 min. The YS, UTS and elongation of as-extruded nanocomposite stirring for $30 \mathrm{~min}$ are $255 \mathrm{MPa}, 134 \mathrm{MPa}$ and $11.5 \%$, respectively, which are approximately $56 \%, 90 \%$ and $283 \%$ greater than that of the as-cast composite (163 MPa, 70 $\mathrm{MPa}$ and $3 \%)$. According to the classic Hall-Petch equation:

$$
\sigma_{\mathrm{y}}=\sigma_{0}+K_{\mathrm{y}} d^{-1 / 2}
$$

YS is proportional to $d^{1 / 2}$, where $d$ is the mean grain size ${ }^{[19]}$. The grains of extruded SiCp/Mg-9Al-1Zn nanocomposites stirring for $30 \mathrm{~min}$ are significantly refined due to increased fine DRXed grains as shown in Fig.3b. As a result the yield strength of nanocomposite is enhanced. Besides, SiC nanoparticles as well as fine $\mathrm{Mg}_{17} \mathrm{Al}_{12}$ particles in the as-extruded nanocomposite are much harder than that of the matrix alloy at room temperature. During tensile test, the deformation of as-extruded nanocomposite needs the dislocation to spread from grains to grains, which is hindered by the $\mathrm{SiC}$ nanoparticles as well as $\mathrm{Mg}_{17} \mathrm{Al}_{12}$ phases along the grain boundaries ${ }^{[20]}$. This Orowan strengthening effect can contribute to the improvement of ultimate tensile strength. In addition, uniform $\mathrm{SiC}$ particle and increased fine DRXed regions exist in the extruded $\mathrm{SiCp} / \mathrm{Mg}-9 \mathrm{Al}-1 \mathrm{Zn}$ nanocomposites stirring for $30 \mathrm{~min}$ resulting in higher elongation.

Table 2 shows a comparison of the reported values of deformed $\mathrm{SiC}$ particles reinforced magnesium matrix composites. As compared with other researches of micron $\mathrm{SiC}$ particles

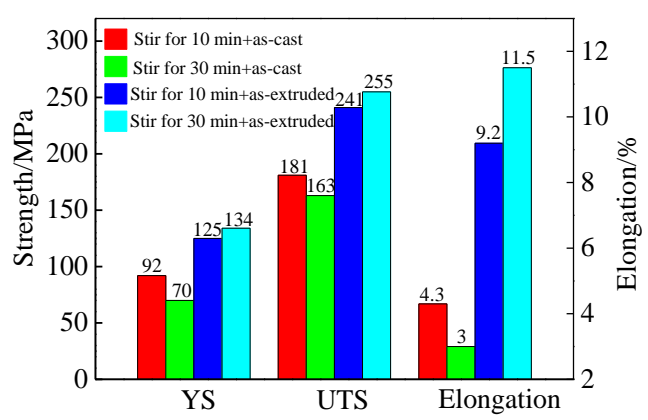

Fig.5 Tensile properties of SiCp/Mg-9Al-1Zn nanocomposite

Table 2 Comparison of reported values of deformed SiCp reinforced magnesium matrix composites

\begin{tabular}{|c|c|c|c|}
\hline Composite & Process & \multicolumn{2}{|c|}{ UTS/MPa Elongation/\% } \\
\hline $\begin{array}{l}60 \mathrm{~nm} 1 \mathrm{wt} \% \\
\text { SiCp/Mg-9Al-1Zn }\end{array}$ & $\begin{array}{l}\text { Extrusion at } 360{ }^{\circ} \mathrm{C} \\
\text { Ratio } 10: 1\end{array}$ & $255 \pm 9$ & $11.5 \pm 1.0$ \\
\hline $\begin{array}{l}0.5 \mu \mathrm{m} 10 \mathrm{vol} \% \\
\mathrm{SiCp} / \mathrm{AZ}_{11} \mathrm{~B}^{[21]}\end{array}$ & $\begin{array}{l}\text { Extrusion at } 350{ }^{\circ} \mathrm{C} \\
\text { Ratio } 12: 1\end{array}$ & $\sim 350$ & $\sim 1.2$ \\
\hline $\begin{array}{l}10 \mu \mathrm{m} \text { 10vol\% } \\
\text { SiCp/AZ91 }{ }^{[22]}\end{array}$ & $\begin{array}{l}\text { Extrusion at } 350{ }^{\circ} \mathrm{C} \\
\text { Ratio } 12: 1\end{array}$ & $\sim 325$ & $\sim 3.9$ \\
\hline $\begin{array}{l}10 \mu \mathrm{m} \text { 9vol\%+60 nn } \\
\text { SiCp/AZ31B }\end{array}$ & $\begin{array}{l}\text { Extrusion at } 350{ }^{\circ} \mathrm{C} \\
\text { Ratio } 12: 1\end{array}$ & $\sim 308$ & $\sim 3.9$ \\
\hline
\end{tabular}

reinforced magnesium matrix composites, the nanocomposite of the present study shows better elongation, which is attributed to the existence of uniformly distributed nanoscale $\mathrm{SiC}$ particles. It is well known that uniformly distributed $\mathrm{SiC}$ nanoparticles can improve ductility of composite significantly. However, as-extruded $60 \mathrm{~nm}$ 1wt\% SiCp/Mg-9Al-1Zn composites don't exhibit the best UTS in this study, which may be due to the higher extrusion temperature and the smaller extrusion ratio.

\section{Conclusions}

1) For as-cast $\mathrm{SiCp} / \mathrm{Mg}-9 \mathrm{Al}-1 \mathrm{Zn}$ nanocomposite stirring for $30 \mathrm{~min}$, the grain size declines contrast to that stirring for 10 min. But a multitude of $\mathrm{SiC}$ nanoparticle clusters locate at the grain boundaries and the $\mathrm{Mg}_{17} \mathrm{Al}_{12}$ phases exhibit network morphology with increasing the stir time.

2) The $\mathrm{Mg}_{17} \mathrm{Al}_{12}$ phases crack into fine particle and the seg- 
regation of $\mathrm{SiC}$ particles is largely eliminated after hot extrusion compared with that of as-cast $\mathrm{SiCp} / \mathrm{Mg}-9 \mathrm{Al}-1 \mathrm{Zn}$ nanocomposite. In addition, fine $\mathrm{Mg}_{17} \mathrm{Al}_{12}$ particles play a major role in the formation of fine DRXed grains.

3) For as-extruded $\mathrm{SiCp} / \mathrm{Mg}-9 \mathrm{Al}-1 \mathrm{Zn}$ nanocomposite, the nanocomposite stirring for $30 \mathrm{~min}$ exhibit superior yield strength, ultimate tensile strength and elongation compared with nanocomposite stirring for $10 \mathrm{~min}$, which is attributed to dispersed $\mathrm{SiC}$ particles and increased fine DRXed regions.

\section{References}

1 Qin L, Ding J, Zhao W M et al. Rare Metal Materials and Engineering $[\mathrm{J}], 2016,45(1): 23$

2 Xie X, Shen J, Cheng Let al. Materials and Design[J], 2015, 81: 31

3 Song S Y, Zhou X, Li L et al. Ultrasonics Sonochemistry[J], 2015, 24: 43

4 Li D Q, Wang Q D, Ding W J et al. Transactions of Nonferrous Metals Society of China[J], 2010, 20: 1311

5 Deng K K, Shi J Y, Wang C J et al. Composites: Part A[J], 2012, 43: 1280

6 Deng K K, Wang C J, Shi J Y et al. Materials Chemistry and Physics[J], 2012, 134: 581

7 Deng K K, Wang C J, Wang X J et al. Materials and Design[J], 2012, 38: 110

8 Nie K B, Wang X J, Wu K et al. Materials Science and Engineering $A[\mathrm{~J}]$, 2011, 528: 8709

9 Nie K B, Wang X J, Xu L et al. Journal of Alloys and Com- pounds $[\mathrm{J}], 2012,512: 355$

10 Nie K B, Wang X J, Hu X S et al. Materials Science and Engineering $A[\mathrm{~J}], 2011,528: 5278$

11 Nie K B, Wang X J, Xu L et al. Materials and Design[J], 2012, 36: 199

12 Nie K B, Wang X J, Wu K et al. Journal of Alloys and Compounds[J], 2011, 509: 8664

13 Li M, Tamura T, Omura N et al. Journal of Materials Processing Technology[J], 2016, 235: 114

14 Shang S J, Deng K K, Nie K B et al. Materials Science and Engineering $A[\mathrm{~J}], 2014,610: 243$

15 Zhou S S, Deng K K, Li J C et al. Materials and Design[J], 2014, 63: 672

16 Wang X J, Hu X S, Nie K B et al. Transactions of Nonferrous Metals Society of China[J], 2012, 22: 1912

17 Hagihara K, Kinoshita A, Sugino Y et al. Acta Materialia[J], 2010, 58: 6282

18 Jung J G, Park S H, Yu H et al. Scripta Materialia[J], 2014, 93: 8

19 Wu K, Deng K K, Nie K B et al. Materials and Design[J], 2010, 31: 3929

20 Li Z F, Dong J, Zeng X Q et al. Materials Science and Engineering $A[\mathrm{~J}], 2007,466: 134$

21 Shen M J, Wang X J, Li C D et al. Materials and Design[J], 2014, 54: 436

22 Wang X J, Xu L, Hu X S et al. Materials Science and Engineering $A[\mathrm{~J}], 2011,528: 6387$

23 Shen M J, Wang X J, Zhang M F et al. Materials Science and Engineering $A[\mathrm{~J}], 2014,601: 58$

\title{
热挤压对不同搅拌时间制备的纳米 SiCp/Mg-9Al-1Zn 复合材料组织和性能的影响
}

\author{
王万华 ${ }^{1,2}$, 王红霞 ${ }^{1,2}$, 任广笑 ${ }^{1,2}$, 程伟丽 ${ }^{1,2}$, 张少雄 ${ }^{1,2}$
}

(1. 太原理工大学 山西省先进镁基材料重点实验室, 山西 太原 030024)

(2. 先进材料表面与工程重点实验室，山西 太原 030024)

摘 要: 通过半固态搅拌铸造和热挤压变形复合工艺制备出 $\mathrm{SiCp}$ 质量分数为 $1 \%$ 的纳米 $\mathrm{SiCp} / \mathrm{Mg}-9 \mathrm{Al}-1 \mathrm{Zn}$ 镁基复合材料。研究了搅拌时间 分别为 10 和 $30 \mathrm{~min}$ 时热挤压对纳米 $\mathrm{SiCp} / \mathrm{Mg}-9 \mathrm{Al}-1 \mathrm{Zn}$ 镁基复合材料的显微组织和力学性能的影响。结果表明, 对于铸态的纳米 $\mathrm{SiCp} / \mathrm{Mg}-9 \mathrm{Al}-$ $1 \mathrm{Zn}$ 镁基复合材料来说, 搅拌时间为 $30 \mathrm{~min}$ 时, 基体的晶粒细化, 但在晶界处析出的 $\mathrm{Mg}_{17} \mathrm{Al}_{12}$ 相数量增多, 网状化严重且 $\mathrm{SiC}$ 团聚增加, 使得复合材料的力学性能下降。而通过热挤压后, 复合材料形成了粗晶与细晶交替的组织结构。特别是对于搅拌时间为 $30 \mathrm{~min}$ 的复合材料, 细晶区增多且纳米 $\mathrm{SiC}$ 颗粒分布更加均匀, 这就使得力学性能高于摚拌 $10 \mathrm{~min}$ 的挤压态的 $\mathrm{SiCp} / \mathrm{Mg}-9 \mathrm{Al}-1 \mathrm{Zn}$ 复合材料。 关键词: $\mathrm{SiCp} / \mathrm{Mg}-9 \mathrm{Al}-1 \mathrm{Zn}$ 纳米复合材料; 搅拌时间; 双峰结构; 力学性能

作者简介: 王万华, 男, 1990 年生, 硕士, 太原理工大学材料科学与工程学院, 山西 太原 030024, 电话: 0351-6018398, E-mail: $528508381 @ q q . c o m$ 